\title{
Percoll Gradient Optimization for Blood CD133+ Stem Cell Recovery
}

\author{
Rosa María López-Franco, Jorge E. Moreno-Cuevas, María Teresa González-Garza* \\ Servicio de Terapia Celular, School of Medicine, CITES, Tecnológico de Monterrey, Monterrey, México \\ Email: ${ }^{*}$ mtgonzalezgarza@itesm.mx
}

Received 3 April 2014; revised 2 May 2014; accepted 1 June 2014

Copyright (C) 2014 by authors and Scientific Research Publishing Inc.

This work is licensed under the Creative Commons Attribution International License (CC BY).

http://creativecommons.org/licenses/by/4.0/

(c) (7) Open Access

\begin{abstract}
Circulating CD133+ stem cells from the peripheral blood have been shown to be able to differentiate into numerous cell lineages. However, adults have only a small number of these circulating stem cells. The aim of the present study was to assess a new isolation and enrichment technique for CD133+ stem cells from peripheral blood with the use of Percoll density gradients. Our results demonstrated the presence of two large mononuclear bands when whole blood was centrifuged with $48 \%$ and $50 \%$ Percoll concentrations. Flow cytometric analysis (FACS) revealed a major CD133+ enrichment at the $\mathbf{4 8 \%}$ Percoll concentration in one of the two bands. Further culture of these cells resulted in the formation of multiple colony-forming units. Our results suggest an advantage from using a simple Percoll gradient for successful CD133+ cell recovery, which could aid in differentiation and transplantation protocols.
\end{abstract}

\section{Keywords}

Stem Cells Recovery, CD133+, Percoll, Density Gradients

\section{Introduction}

There are some multipotent adult stem cells in the bone marrow. These cells have the capacity to differentiate into numerous cell lineages, such as cartilage, bone, fat, muscle, neuron and tendon [1]-[6]. This fact makes them attractive candidates for cell and gene therapy.

It has been shown that stem cells are also resident in other tissues, including blood [7], which raise the possibility of having an accessible and less traumatic source. In addition, peripheral blood stem cells are known to be capable of regenerating damaged or diseased tissues [8] [9].

Stem cells express CD133 antigen [10] [11]. CD133, therefore, is an antigen that could serve as an alternative ${ }^{*}$ Corresponding author.

How to cite this paper: López-Franco, R.M., Moreno-Cuevas, J.E. and González-Garza, M.T. (2014) Percoll Gradient Optimization for Blood CD133+ Stem Cell Recovery. Stem Cell Discovery, 4, 61-66.

http://dx.doi.org/10.4236/scd.2014.43007 
to CD34 for the selection and expansion of stem cells for transplantation and differentiation into several cell lineages. The CD133+ progenitors have been shown to be capable to form colony-forming units (CFUs) in vitro, and transplantation into NOD/SCID mice resulted in a high engraftment rate with conservation of its multilineage capacity [12]-[14]. CD133+ progenitors cells have also been used for autologous transplantation [15] [16] and demonstrate its capability to differentiate into motor preneurons in vitro [17].

Percoll has been widely used to selectively separate cells by their density characteristics. It has also been shown to be efficient in separating mononuclear cells from erythrocytes out of whole blood samples [18], as well as from bone marrow [19] and umbilical cord blood [20]. Additionally, it has been used to isolate many cell organelles [21].

The aim of this study was to optimize the use of Percoll gradients for the isolation of CD133+ stem cells from peripheral blood samples from adult.

\section{Material and Methods}

\subsection{Blood Samples}

Fifteen-milliliter samples of peripheral blood were obtained by venipuncture from healthy human adult volunteers. Heparin was used as an anticoagulant. The blood was diluted 1:2 with phosphate buffer saline (PBS) and 2 $\mathrm{mL}$ was carefully added to a $1 \mathrm{~mL}$ Percoll gradient.

\subsection{Percoll Gradients}

The cells were fractionated on a discontinuous density gradient prepared with the following Percoll (Research Organics, Cleveland, OH, USA) concentrations: 70\%, 65\%, 50\%, 48\%, 46\% and $44 \%$ in PBS. After centrifugation $(450 \times g$ for $30 \mathrm{~min})$ the resulting bands were collected and washed twice with PBS. A Lycoprep sample was used as a control.

\subsection{Density Determination}

Density gradient determination was assessed using a $9.901 \mathrm{~cm}^{3}$ pycnometer (Brand, Germany) calibrated at $17^{\circ} \mathrm{C}$. Determinations were taken at $18^{\circ} \mathrm{C}$. All determination was performed by triplicate.

\subsection{Flow Cytometric Analysis}

The total blood cell contents of the different bands recovered were stained with fluorescein isothiocyanate (FITC)-conjugated anti-CD34 (HPCA-2-FITC; Becton Dickinson, New Jersey, USA) and phycoerythrin (PE)conjugated anti-AC133 (Miltenyi Biotec Bergisch Gladbach, Germany) for $60 \mathrm{~min}$ on ice in the dark. After incubation, the cells were washed once in PBS. Cell sorting was performed on a FACS Vantage (Becton Dickinson) equipped with an argon laser tuned to $488 \mathrm{~nm}$. Determinations were performed by triplicate.

\subsection{Cell Culture}

Cells from the recovered bands were incubated in separate Petri dishes with DMEM-F12 media supplemented with $10 \%$ fetal bovine sera (FBS) at $37^{\circ} \mathrm{C}$ in $5 \% \mathrm{CO}_{2}$ in air. The cultures were followed with an inverted microscope.

\section{Results}

\section{Density Determination}

All densities analyzed formed a mononuclear band with good resolution. Table 1 shows the density determination performed on the different Percoll concentrations used, as well the band number formed.

Densities of $48 \%$ and $50 \%$ gave the best resolution, in that a wide band (b) formed between the erythrocytes (a) and a second thin band (c) below the serum fraction (d) (Figure 1).

Data from FACS showed a high number of $\mathrm{CD}_{133^{+}}$as well CD34 ${ }^{+}$cells in band (b). At 48\% Percoll, corresponding to 1.06112 (Figure 2).

FACS analyses demonstrated a higher number of CD133+ cells compared with the Lycoprep as control and 
Table 1. Density from different Percoll concentration and number of bands recovery.

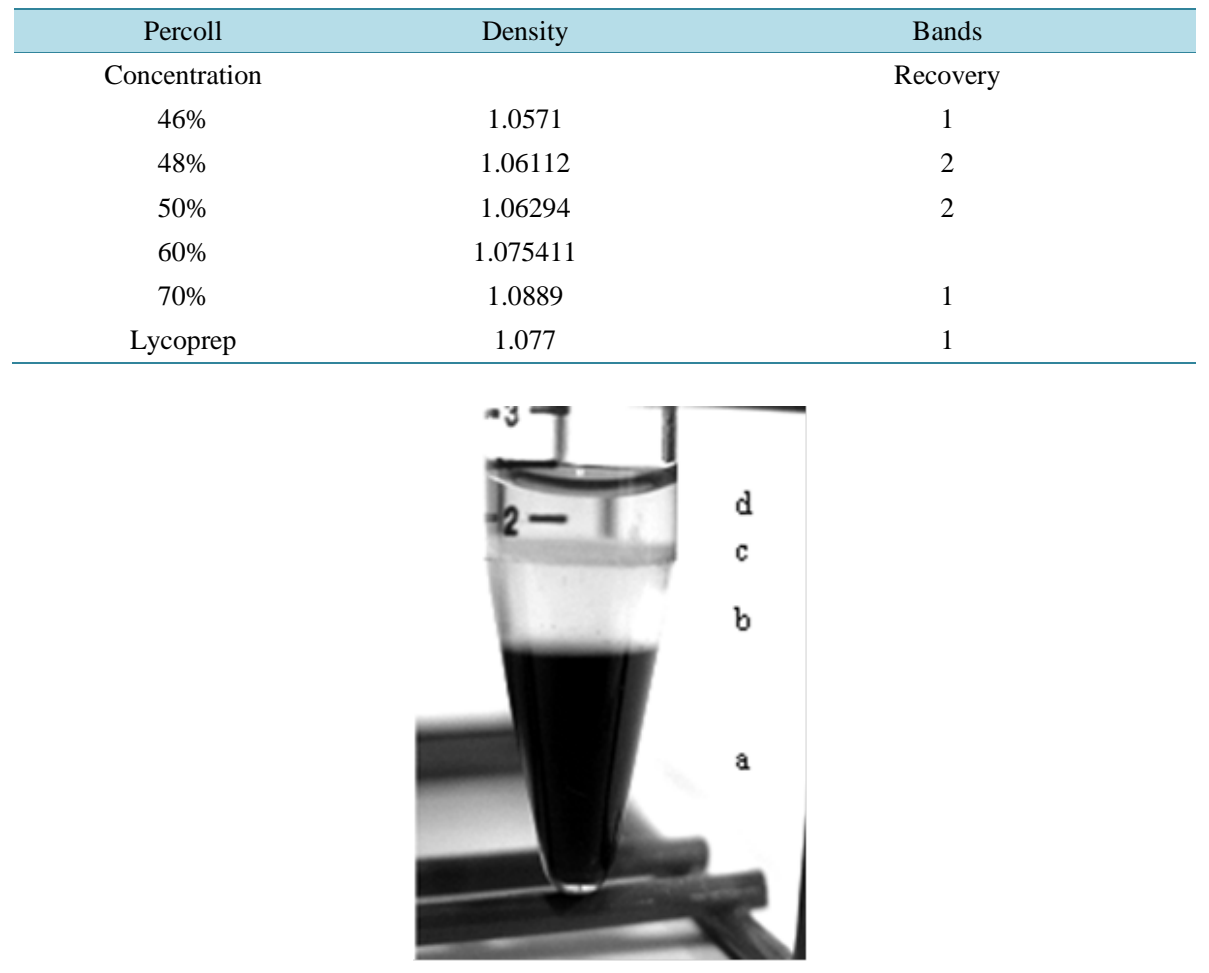

Figure 1. Photography of $48 \%$ Percoll concentration bands. (a) erythrocyte pellet; (b) wide mononuclear band; (c) thin mononu-clear band; (d) sera band.

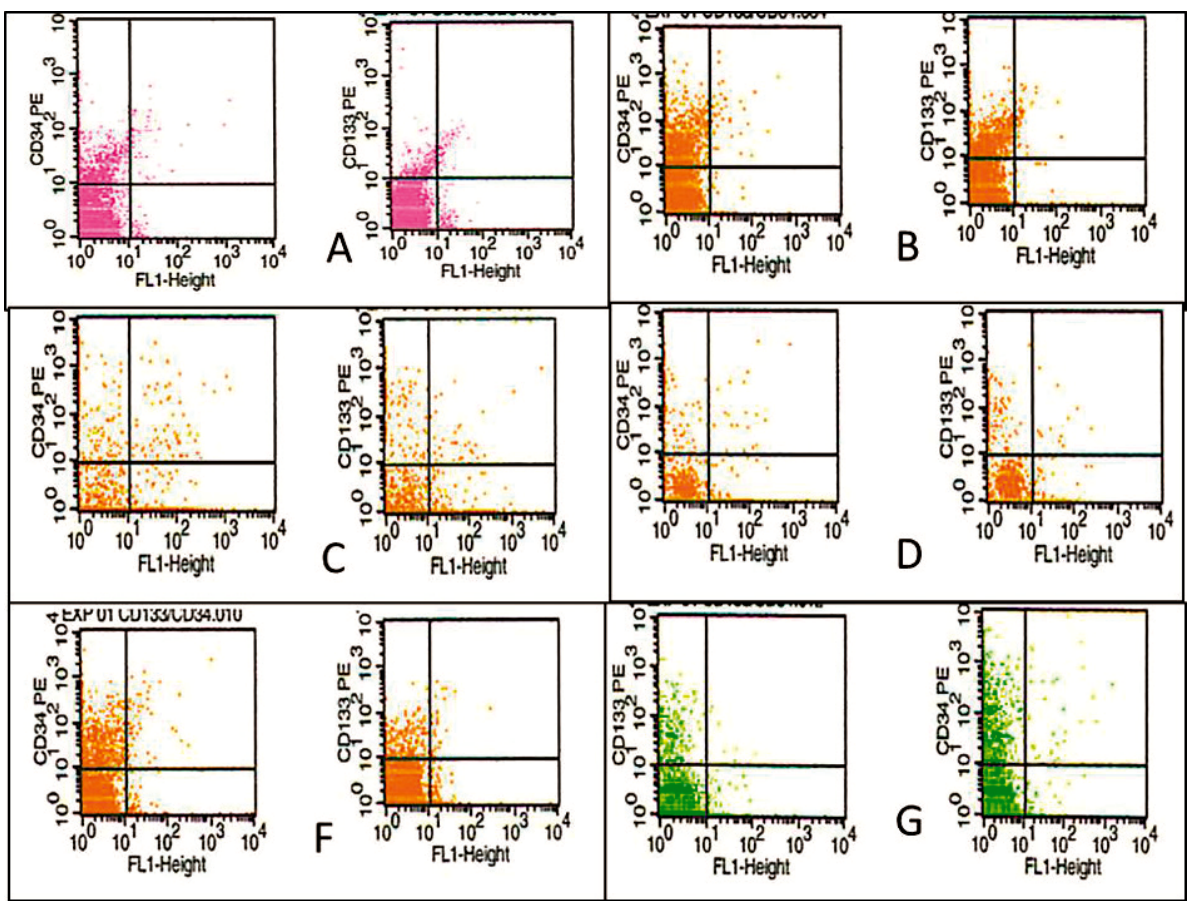

Figure 2. FACS of CD34+ and CD133+ cells analisys on total blood and different concentration of Percoll density. (A) total blood; (B) Lycoprep; (C) 46\%; (D) 48\% Percoll; (E) 50 \%; (F) 60\% Percoll. 
with the other Percoll concentration. The percentages of CD34+ and CD133+ cells recovered are shown in Table 2.

All cells isolated with the use of the $48 \%$ Percoll concentration produced viable cultures (Figure 3) with multiple CFU.

\section{Discussion}

Percoll at $70 \%$ concentration is prevalent in stem cell separation protocols [22]. This concentration corresponds to a 1.0889 density, which is higher than that reported for mononuclear cells. However, the density of 1.075 obtained from a $60 \%$ Percoll concentration, is similar to that obtained from commercial preparations. This concentration gave a good resolution for CD34+ cells, but not for CD133+ cells [23]. The median percentage of CD133+ recovery with this approach is $0.75 \%$ (range $0.39 \%-2.03 \%$ ) [12]. Our results show that a $48 \%$ Percoll concentration gave $12.62 \%$ recovery of $\mathrm{CD} 133+$ cells. These data represent an important difference for protocols aimed at transplantation and/or differentiation. It has been shown that CD133+ cells are the choice in many instances, because of their lower conversion to malignancy [15]. Furthermore, CD133+ cells have been shown to present a higher plasticity for differentiation into endothelial cells [23] and neurons [15] [24].

\section{Conclusion}

The use of 1.061 densities (48\% Percoll) for gradient separation of CD133+ cells from peripheral blood, gives better yields than the use of 1.077 densities, commonly used for gradient isolation of stem cells, in particular those which carry the Antigen CD133+.

\section{Acknowledgements}

Authors express their appreciation to Carlos A. Morales for density performed of Percoll samples. This work

Table 2. Percentage recovery of CD34+ and CD133+ cells from different band b Percoll concentration.

\begin{tabular}{ccc}
\hline Percoll Concentration & \%CD34+ & \%CD133+ \\
\hline Total blond & 7.05 & 2.68 \\
Lycoprep & 12.34 & 7.70 \\
Percoll 46\% & 12.87 & 11.27 \\
Percoll 48\% & 11.53 & 12.62 \\
Percoll 50\% & 6.84 & 5.35 \\
Percoll 60\% & 15.58 & 4.03 \\
\hline
\end{tabular}

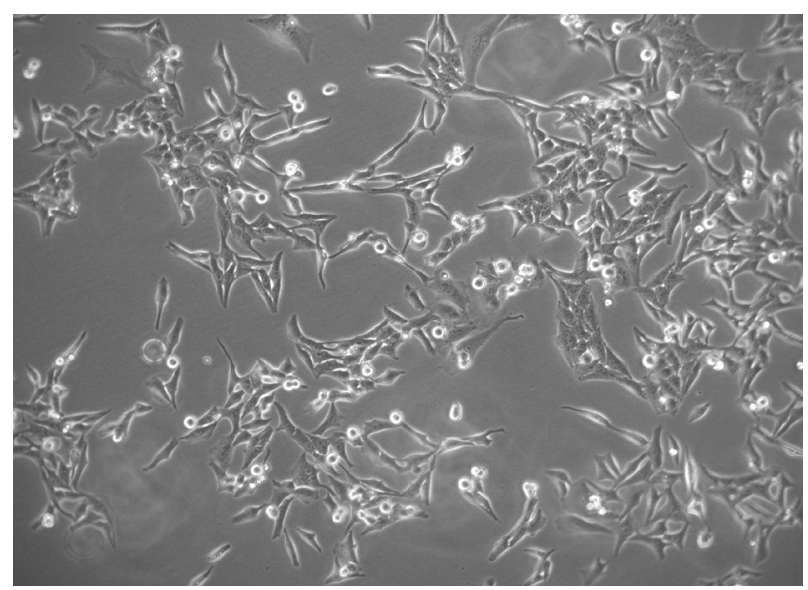

Figure 3. Microphotography of cells incubated with DMEMF12 medium after 20 days recovery from $48 \%$ Percoll concentration. Multiple rounded mitotic cells are observed. 
was partially funded by endowments from Instituto Tecnológico de Estudios Superiores de Monterrey (cat-134) and the Zambrano-Hellion Foundation

\section{References}

[1] Ballas, C.B., Zielske, S.P. and Gerson, S.L. (2002) Adult Bone Marrow Stem Cells for Cell and Gene Therapies: Implications for Greater Use. Journal of Cellular Biochemistry, Supplement, 38, 20-28. http://dx.doi.org/10.1002/jcb.10127

[2] Pereira, R.F., O’Hara, M.D., Laptev, A.V., Haldford, K.W., Pollard, M.D., Class, R., Simon, D., Livezey, K. and Prockop, D.J. (1998) Marrow Stromal Cells as a Source of Progenitor Cells for Nonhematopoietic Tissues in Transgenic Mice with a Phenotype of Osteogenesis Imperfecta. Proceedings of the National Academy of Sciences of the United States of America, 95, 1142-1147. http://dx.doi.org/10.1073/pnas.95.3.1142

[3] Hofstetter, C.P., Schwarz, E.J., Hess, D., Widenfalk, J., El Manira, A., Prockop, D.J. and Olson, L. (2002) Marrow Stromal Cells Form Guiding Strands in the Injured Spinal Cord and Promote Recovery. Proceedings of the National Academy of Sciences of the United States of America, 99, 2199-2204. http://dx.doi.org/10.1073/pnas.042678299

[4] Jiang, Y., Jahagirdar, B.N., Reinhardt, R.L., Schwartz, R.E., Keene, C.D., Ortiz-Gonzalez, X.R., Reyes, M., Lenvik, T., Lund, T., Blackstad, M., Du, J., Aldrich, S., Lisberg, A., Low, W.C., Largaespada, D.A. and Verfaillie, C.M. (2002) Pluripotency of Mesenchymal stem Cells Derived from Adult Marrow. Nature, 418, 41-49. http://dx.doi.org/10.1038/nature00870

[5] Pereira, R.F., Haldford, K.W., O’Hara, M.D., Leeper, D.B., Sokolov, B.P., Pollard, M.D., Bagasra, O. and Prockop, D.J. (1995) Cultures Adherent Cells from Marrow Can Serve as Long-Lasting Precursor Cells for Bone, Cartilage, and Lung in Irradiated Mice. Proceedings of the National Academy of Sciences of the United States of America, 92, 4857-4861.

[6] Pittenger, M.F., Mackay, A.M., Beck, S.C., Jaiswal, R.K., Douglas, R., Mosca, J.D., Moorman, M.A., Simonetti, D.W., Craig, S. and Marshak, D.R. (1999) Multilineage Potential of Adult Human Mesenchymal Stem Cells. Science, 284, 143-147. http://dx.doi.org/10.1126/science.284.5411.143

[7] Zvaifler, N.J., Marinova-Mutafchieva, L., Adams, G., Edwards, C.J., Moss, J., Burger, J.A. and Maini, R.N. (2002) Mesenchymal Precursor Cells in the Blood Of Normal Individuals. Arthritis Research, 2, 477-488. http://dx.doi.org/10.1186/ar130

[8] Assmus, B., Schächinger, V., Teupe, C., Britten, M., Lehmann, R., Döbert, N., Grünwald, F., Aicher, A., Urbich, C., Martin, H., Hoelzer, D., Dimmeler, S. and Zeiher, A.M. (2002) Transplantation of Progenitor Cells and Regeneration Enhancement in Acute Myocardial Infarction (TOPCARE-AMI). Circulation, 106, 3009-3017. http://dx.doi.org/10.1161/01.CIR.0000043246.74879.CD

[9] Balducci, E., Azzarello, G., Valenti, M.T., Capuzzo, G.M., Pappagallo, G.L., Pilotti, I., Ausoni, S., Bari, M., Rosetti, F., Sartori, D., Ciappa, A., Porcellini, A. and Vinante, O. (2003) The Impact of Progenitor Enrichment, Serum, and Cytokines on the Ex Vivo Expansion of Mobilized Peripheral Blood Stem Cells: A Controlled Trial. Stem Cells, 21 , 33-40. http://dx.doi.org/10.1634/stemcells.21-1-33

[10] Yin, A.H., Miraglia, S., Zanjani, E.D., Almeida-Porada, G., Ogawa, M., Leary, A.G., Olweus, J., Kearney, J. and Buck, D.W. (1997) AC133, a Novel Marker for Human Hematopoietic Stem and Progenitor Cells. Blood, 90, 5002-5012.

[11] Matsumoto, K., Yasui, K., Yamashita, N., Horie, Y., Yamada, T., Tani, Y., Shibata, H. and Nakano, T. (2000) In Vitro Proliferation Potential of AC133 Positive Cells in Peripheral Blood. Stem Cells, 18, 196-203. http://dx.doi.org/10.1634/stemcells.18-3-196

[12] Gordon, P.R., Leimig, T., Babarin-Dorner, A., Houston, J., Holladay, M., Mueller, I., Geiger, T. and Handgretinger, R. (2003) Large-Scale Isolation of CD133+ Progenitor Cells from G-CSF Mobilized Peripheral Blood Stem Cells. Bone Marrow Transplantation, 31, 17-22. http://dx.doi.org/10.1038/sj.bmt.1703792

[13] Kobari, L., Giarratana, M.C., Pflumio, F., Izac, B., Coulombel, L. and Douay, L. (2001) CD133+ Cell Selection Is an Alternative to CD34+ Cell Selection for Ex Vivo Expansion of Hematopoietic Stem Cells. Journal of Hematotheray and Stem Cell Research, 10, 273-281. http://dx.doi.org/10.1089/15258160151134980

[14] Kuci, S., Wessels, J.T., Buhring, H.J., Schilbach, K., Schumm, M., Seitz, G., Loffler, J., Bader, P., Schlegel, P.G., Niethammer, D. and Handgretinger, R. (2003) Identification of a Novel Class of Human Adherent CD34-Stem Cells That Give Rise to SCID-Repopulating Cells. Blood, 101, 869-876. http://dx.doi.org/10.1182/blood-2002-03-0711

[15] Koehl, U., Zimmermann, S., Esser, R., Sorensen, J., Gruttner, H.P., Duchscherer, M., Seifried, E., Klingebiel, T. and Schwabe, D. (2002) Autologous Transplantation of CD133 Selected Hematopoietic Progenitor Cells in a Pediatric Patient with Relapsed Leukemia. Bone Marrow Transplantation, 29, 927-930. http://dx.doi.org/10.1038/sj.bmt.1703558

[16] Martinez, H.R., Gonzalez Garza, M.T., Moreno Cuevas, J.E., Caro Osorio, E., Gutierrez, E. and Segura, J.J. (2009) Stem-Cell Transplantation into the Frontal Motor Cortex in Amyotrophic Lateral Sclerosis Patients. Cytoyherapy, 11, 
26-34. http://dx.doi.org/10.1080/14653240802644651

[17] Gonzalez Garza, M.T., Moreno Cuevas, J.E., Martinez, H.R., Caro Osorio, E., Cruz-Vega, D.E. and Hernandez-Torre, M. (2013) Differentiation of CD133+ Stem Cells from Amyotrophic Lateral Sclerosis Patients into Neuron-Like Cells. Stem Cell Translational Medicine, 2, 129-135.

[18] Kato, M., Kato, Y. and Sugiyama, Y. (1999) Mechanism of the Upregulation of Erythropoietin-Induced Uptake Clearance by the Spleen. American Journal of Physiology, 276, E887-E895.

[19] Cowland, J.B. and Borregaard, N. (1999) Isolation of Neutrophil Precursors from Bone Marrow for Biochemical and Transcriptional Analysis. Journal of Immunology Methods, 232, 191-200. http://dx.doi.org/10.1016/S0022-1759(99)00176-3

[20] Li, C.D., Zhang, W.Y., Li, H.L., Jiang, X.X., Zhang, Y., Tang, P. and Mao, N. (2005) Mesenchymal Stem Cells Derived from Human Placenta Suppress Allogeneic Umbilical Cord Blood Lymphocyte Proliferation. Cell Research, 15, 539-547. http://dx.doi.org/10.1038/sj.cr.7290323

[21] Pertoft, H. (2000) Fractionation of Cells and Subcellular Particles with Percoll. Journal of Biochemical and Biophysical Methods, 44, 1-30. http://dx.doi.org/10.1016/S0165-022X(00)00066-X

[22] Lazarus, H.M., Haynesworth, S.E., Gerson, S.L., Rosenthal, N.S. and Caplan, A.I. (1995) Ex Vivo Expansion and Subsequent Infusion of Human Bone Marrow-Derived Stromal Progenitor Cells (Mesenchymal Progenitor Cells): Implications for Therapeutic Use. Bone Marrow Transplantation, 16, 557-564.

[23] Quirici, N., Soligo, D., Caneva, L., Servida, F., Bossolasco, P. and Deliliers, G.L. (2001) Differentiation and Expansion of Endothelial Cells from Human Bone Marrow CD133(+) Cells. Journal of Haematology, 115, 186-194.

[24] Sawamoto, K., Nakao, N., Kakishita, K., Ogawa, Y., Toyama, Y., Yamamoto, A., Yamaguchi, M., Mori, K., Goldman, S.A., Itakura, T. and Okano, H. (2001) Generation of Dopaminergic Neurons in the Adult Brain from Mesencephalic Precursor Cells Labeled with a Nestin-GFP Transgene. Journal of Neuroscience, 21, 3895-3903. 
Scientific Research Publishing (SCIRP) is one of the largest Open Access journal publishers. It is currently publishing more than 200 open access, online, peer-reviewed journals covering a wide range of academic disciplines. SCIRP serves the worldwide academic communities and contributes to the progress and application of science with its publication.

Other selected journals from SCIRP are listed as below. Submit your manuscript to us via either submit@scirp.org or Online Submission Portal.
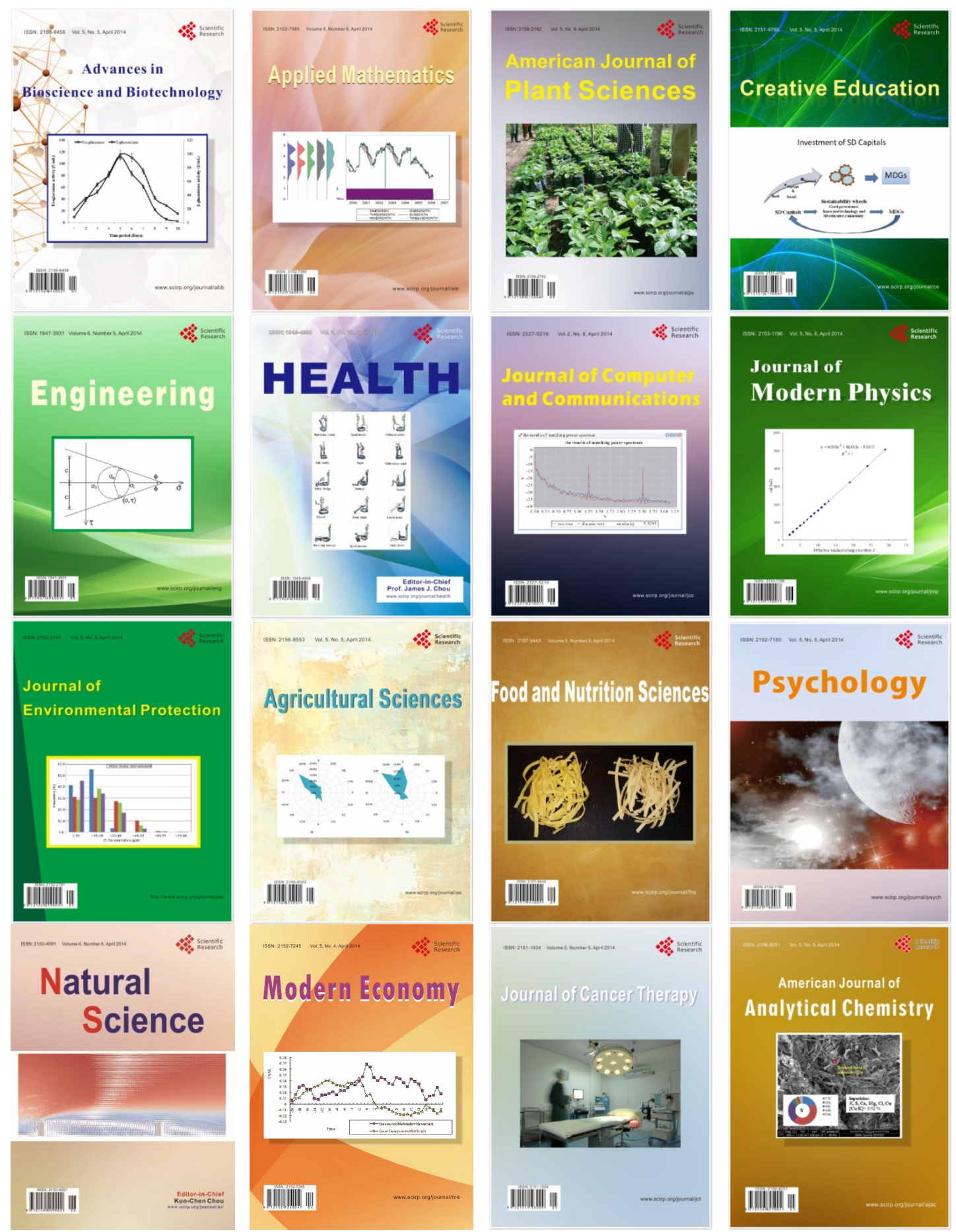